\title{
Penerapan metode k-means clustering data COVID-19 di Provinsi Jakarta
}

\section{Implementation of k-means method for COVID-19 data clustering in Jakarta Province}

\author{
Meida Cahyo Untoro a, Leslie Anggraini b, ${ }^{*}$, Maria Andini c, Hesti Retnosari d, M. Anas \\ Nasrullohe

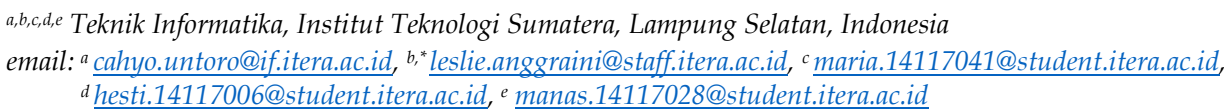

\section{N F O A R T I K E L}

Sejarah artikel:

Menerima 16 Februari 2021

Revisi 10 Maret 2021

Diterima 27 Maret 2021

Online 5 April 2021

\section{Kata kunci:}

corona

COVID-19

k-means

pandemik

pengelompokan

\section{Keywords:}

corona

COVID-19

clustering

$k$-means

pandemic

Style APA dalam menyitas artikel ini:

Untoro, M. C., Anggraini, L., Andini, M., Retnosari, H., \& Nasrulloh, M. A. (2021).

Penerapan metode k-means clustering data COVID-19 di Provinsi Jakarta. Teknologi: Iurnal Ilmiah Sistem Informasi, 11(2), 59-68.

\begin{abstract}
ABSTRAK
Wabah penyakit yang menyerang area pernafasan dan terdeteksi masuk di Indonesia pada awal tahun 2020 adalah Virus Corona (COVID-19). Penyebaran virus ini cukup mudah melalui droplet dari pasien terjangkit, sehingga penyebarannya sangat pesat. Penelitian ini dilakukan untuk mengklasterisasi data kasus COVID-19 di Provinsi Jakarta. Hal ini mengingat bahwa Jakarta merupakan titik awal kasus pertama Corona di Indonesia. Hingga kini, Jakarta menjadi salah satu penyumbang kasus COVID-19 terbesar di Indonesia dengan kasus positif per bulan Desember 2020 mencapai 154.000 jiwa dengan kesembuhan 139.000 jiwa. Pengelompokkan dilakukan berdasarkan parameter pasien positif dan meninggal dari masing-masing kelurahan yang ada di Provinsi Jakarta. Penelitian ini menggunakan algoritma $k$-means untuk melakukan klasterisasi dalam penanganan kasus COVID-19 dengan 2 cluster. Persebaran data pada cluster 1 terdapat 173 data, dan 18 data pada cluster 2 . Penggunaan $k$-means pada penelitian ini memberikan informasi daerah-daerah yang memiliki jumlah kasus positif dan tingkat kesembuhan tertinggi maupun terendah yang dapat dijadikan sebagai evaluasi dalam proses penanganan virus COVID-19.
\end{abstract}

\section{ABSTRACT}

The disease epidemic that attacked the respiratory area and was detected in Indonesia starting in early 2020 is the Corona Virus (COVID-19). This virus's spread is relatively easy, namely through droplets from infected patients, so that the spread is very rapid. This research was conducted to cluster the data on Covid-19 cases in Jakarta Province considering that Jakarta is the starting point for the first case of Corona in Indonesia and until now has become one of the most significant contributors to COVID-19 issues in Indonesia, namely as of December 2020 positive cases of Covid-19 reached 154,000. Souls with the healing of 139.0000 souls. The grouping was carried out based on positive and dead patients from each urban village in Jakarta Province. This study uses the k-means Method to cluster in the handling of COVID-19 cases with 2 clusters. Data distribution in cluster 1 consists of 173 data and 18 data in cluster 2 . The use of $k$-means in this study provides information on areas with the highest and lowest number of positive cases and the highest and lowest cure rates that can be used as an evaluation in handling the Covidvirus 19.

Teknologi: Jurnal IImiah Sistem Informasi dengan lisensi CC BY NC SA.

\section{Pendahuluan}

Saat ini berbagai negara di seluruh dunia sedang dilanda pandemi virus COVID-19. COVID-19 menginfeksi sistem pernapasan manusia yang disebabkan oleh SARS-CoV-2 (Noviyanto, 2020; Dwitri, 
Tampubolon, Prayoga, Zer, \& Hartama, 2020). Virus ini ditemukan di Provinsi Wuhan, China yang diperkirakan pada akhir Desember 2019 untuk pertama kalinya muncul (Sindi, Ningse, Sihombing, Zer, \& Hartama, 2020). Tidak dapat kita pungkiri juga bahwa penyebaran COVID-19 terus bergerak signifikan dikarenakan penyebaran virus ini cukup mudah, di mana penularannya melalui droplet dari pasien terjangkit. Penyebaran virus yang tergolong mudah ini menimbulkan ketakutan serta keresahan bagi masyarakat Indonesia (Rembulan, Wijaya, Palullungan, Alfina, \& Qurthuby, 2020), sehingga pemerintah memberlakukan kebijakan-kebijakan salah satunya adalah Pembatasan Sosial Berskala Besar (PSBB) (Lesmana, Akbari, Rahman, \& Gustian, 2020).

Sejak mulai terdeteksi pada awal tahun 2020, kasus COVID-19 di Indonesia bertambah begitu pesat. Provinsi Jakarta merupakan titik awal ditemukannya kasus Corona pertama di Indonesia. Provinsi Jakarta menjadi salah satu penyumbang kasus COVID-19 terbesar di Indonesia. Data pemantauan COVID-19 sejak tanggal 21 Januari 2020 hingga 4 April 2021 kasus positif COVID-19 mencapai 386.466 jiwa dengan kesembuhan 373.565 jiwa atau setara 96,7\% (Jakarta, 2021).

Penelitian ini bertujuan untuk melakukan clustering terhadap data persebaran virus corona terutama di wilayah Provinsi Jakarta dengan menggunakan data-data yang telah disajikan pada portal http://data.jakarta.go.id. Data tersebut dapat dianalisis terkait peta penyebaran virus corona yang sebenarnya dari waktu ke waktu di Provinsi Jakarta.

Clustering adalah metode pada data mining yang digunakan untuk melakukan pengelompokkan data yang memiliki karakteristik mirip ataupun sama menjadi sebuah cluster (Bastian, Sujadi, \& Febrianto, 2018). Sedangkan untuk data yang memiliki karakteristik berbeda (Untoro \& Buliali, 2018) akan dikelompokkan menjadi cluster baru (Gustientiedina, Adiya, \& Desnelita, 2019). Metode clustering berbeda dengan metode classification dalam penyelesaian dataset (Untoro, et al., 2020). Proses algoritma clustering adalah mencari data pada seluruh set dan menjadikannya subkelompok, yang mana kesamaan data yang berada dalam cluster akan dimaksimalkan, dan kesamaan data yang berada dalam luar cluster akan dimeminimalkan (Taslim \& Fajrizal, 2016).

Salah satu metode clustering yang sangat terkenal adalah algoritma $k$-means, karena $k$-means memiliki algoritma yang sederhana dan efisien. Sehingga $k$-means mudah untuk dipelajari (Gustientiedina, Adiya, \& Desnelita, 2019). k-means merupakan metode yang cukup tangguh untuk digunakan di berbagai jenis data (Solichin \& Khairunnisa, 2020). Oleh karena itu pada penelitian ini $k$ means dipilih untuk proses klasterisasi pada data persebaran COVID-19 di wilayah Jakarta. Hasil dari clustering ini nantinya diharapkan dapat menunjukkan perbedaan persebaran kasus COVID-19 di setiap wilayah pada Provinsi Jakarta yang dibagi berdasarkan kelurahannya. Informasi ini dapat digunakan untuk menentukan strategi yang dapat dilakukan untuk pencegahan penyebaran COVID-19 oleh pemerintah.

\section{State of the Art}

Pada penelitian sebelumnya belum ada penelitian yang berfokus untuk menerapkan metode $k$-means dalam mengklasifikasi persebaran kasus COVID-19 di wilayah Jakarta berdasarkan tingkat kelurahan. Sindi, Ningse, Sihombing, Zer, \& Hartama (2020) menerapakan algoritma k-Medoids untuk mengelompokan penyebaran COVID-19 di Indonesia. Hasil yang didapatkan adalah masyarakat cenderung terinfeksi COVID-19 di wilayahnya masing-masing. Penelitian tersebut menghasilkan jumlah cluster terbaik sebanyak 3 cluster. Cluster 1 memiliki 1 anggota, cluster 2 memiliki 2 anggota, dan cluster 3 memiliki 31 anggota.

Dwitri, Tampubolon, Prayoga, Zer, \& Hartama (2020) menggunakan k-means untuk mengelompokkan data COVID-19 agar mengetahui persebaran penyakit di Indonesia. Persebaraan centroid dari hasil clustering dengan k-means meliputi daerah Jakarta, Jawa Barat, dan Banten. Jakarta salah satu daerah yang memiliki persebaran data COVID-19 cukup tinggi, Jawa Barat pontesial sedangkan Banten cukup potensial.

Suwandi, Situmorang, \& Rakhmawati (2021) dalam penelitiannya mengungkapkan bahwa applikasi tracking COVID-19 akan sangat membatu pemerintah dalam menanggulani persebaran COVID-19 dengan tetap menjaga kerahasiaan data pribadi pengguna aplikasi. Hal tersebut sejalan dengan pengolahan dan penyimpanan data menurut SPBE berdasarkan PERPRES RI No. 95 Th 2018 
bahwa segala data yang bersifat pribadi sangat dijaga sehingga applikasi yang digunakan lebih aman dan nyaman bagi pengguna.

Fitriana, Saragih, \& Hasyati (2018) dalam penelitiannya mengusulkan rancangan model sistem inteligensia bisnis untuk proses analisis dan pengukuran pemasaran produk di pabrik roti yang menggunakan metode $k$-means. Hasil penelitiannya memperoleh $83 \%$ pada cluster 1 yang merupakan ketegori sisa roti rendah dan $17 \%$ pada cluster 2 merupakan sisa roti tinggi.

Indraputra \& Fitriana (2020) dalam penelitiannya mengunakan $k$-means dengan bantuan software Microsoft Excel, Weka, dan KNIME dalam mengelompokkan tingkat terjangkit dan kematian yang disebabkan oleh COVID-19. Hasil diperoleh yaitu pada cluster 2 memiliki jumlah terjangkit dan meninggal lebih tinggi dibandingkan dengan cluster 1. Sehingga daerah-daerah cluster tersebut perlu diprioritaskan penanganannya.

Zubair, et al (2020) menyatakan bahwa penerapan machine learning dan data science dalam bidang kesehatan, salah satunya adalah untuk menentukan kelompok kualitas perawatan kesehatan di negaranegara dengan menggunakan dataset COVID-19. Proses clustering menggunakan algoritma $k$-means sudah teruji lebih efisien dalam menentukan pusat awal cluster.

Maulida (2018) menerapkan data mining dengan menggunakan $k$-means untuk mengelompokkan jumlah kunjungan wisatawan asing yang berada di Provinsi DKI Jakarta. Jumlah cluster dibentuk berdasarkan jumlah kunjungan wisata. Terdapat 3 cluster. Cluster pertama (C1) merupakan jumlah kunjungan wisatawan tinggi, cluster kedua (C2) adalah jumlah kunjungan wisatawan sedang, dan cluster ketiga (C3) adalah jumlah kunjungan wisatawan rendah. C1 berjumlah 1 data, C2 berjumlah 2 data dan C3 memiliki jumlah tertinggi yaitu 5 data. Hasil clustering menjadi catatan bagi pemerintah Provinsi DKI. Jakarta untuk lebih memperhatikan tempat wisata yang berada di cluster C3 supaya dapat lebih maju seperti tempat wisata yang berada pada cluster C2 dan C1.

Budiman \& Rudianto (2019) menggunakan metode k-means dalam mengelompokan wilayah instansi pendaftar yang berada di daerah kota Serang. Hasil ini akan digunakan sebagai acuan daerah mana saja yang berpotensi mendatangkan mahasiswa baru, supaya jumlah mahasiswa baru setiap tahunnya dapat terus meningkat.

\section{Metode Penelitian}

\subsection{Pengumpulan data}

Data yang digunakan dalam penelitian ini adalah data jumlah penduduk Jakarta dan data penyebaran COVID-19 di wilayah Jakarta. Tabel 1 diperoleh dari web Jakarta Open Data.

Tabel 1 Dataset COVID-19 Jakarta

\begin{tabular}{|c|c|c|c|c|c|c|c|}
\hline ID-KEL & KECAMATAN & KELURAHAN & SUSPEK & $\begin{array}{c}\text { JUMLAH } \\
\text { PENDUDUK }\end{array}$ & POSITIF & SEMBUH & MENINGGAL \\
\hline 3171011001 & Pasar Minggu & Pejaten Timur & 228 & 67.989 & 46 & 28 & 4 \\
\hline 3171011002 & Cilincing & Rorotan & 165 & 50.167 & 10 & 4 & 1 \\
\hline 3171011003 & Grogol Petamburan & Tomang & 302 & 8.843 & 91 & 59 & 2 \\
\hline n....... & $\ldots \ldots \ldots$ & $\ldots \ldots \ldots$ & $\cdots \cdots$ & -........ & $\ldots \ldots$ & $\ldots \ldots$ & $\ldots \ldots \ldots$ \\
\hline$\ldots \ldots \ldots$ & $\ldots \ldots \ldots$ & $\ldots \ldots \ldots$ & $\ldots \ldots$ & $\ldots \ldots \ldots$ & $\cdots \cdots$ & $\cdots \cdots$ & $\ldots \ldots \ldots$ \\
\hline$\ldots \ldots \ldots$ & $\ldots \ldots \ldots$ & $\ldots \ldots \ldots$ & $\cdots \cdots$ & $\ldots \ldots \ldots$ & $\cdots \cdots$ & $\cdots \cdots$ & $\ldots \ldots \ldots$ \\
\hline 3175101006 & Cilandak & Gandaria Selatan & 159 & 52.945 & 6 & 2 & 1 \\
\hline 3175101007 & Koja & Rawa Badak Selatan & 215 & 53.360 & 37 & 26 & 2 \\
\hline
\end{tabular}

\subsection{Clustering}

Pada penelitian ini, algoritma $k$-means digunakan untuk clustering. Algoritma k-means merupakan algoritma yang bertujuan untuk mengelompokkan data menjadi beberapa cluster berdasarkan jarak terdekat (Indraputra \& Fitriana, 2020). Gambar 1 merupakan diagram alir yang menggambarkan proses clustering yang dilakukan oleh $k$-means.

Jumlah cluster ( $k$ ) atau nilai arbitrer ditentukan dengan menggunakan metode Elbow. Menurut Madhulatha (2012), metode Elbow merupakan metode yang digunakan untuk menentukan jumlah cluster terbaik dengan cara melihat titik yang membentuk siku, yang mana itu merupakan persentase dari hasil perbandingan antara jumlah cluster. Setelah nilai $k$ didapatkan, maka akan diukur kualitasnya 
menggunakan Sillhouette Coefficient. Sillhouette Coefficient akan mengukur sebarapa dekat setiap objek dalam satu cluster dengan objek di cluster lain (Ogbuabor \& Ugwoke, 2018). Menurut Kaufman \& Rousseeuw (2005), Sillhouette Coefficient adalah kriteria untuk menilai atau mengukur baik tidaknya hasil clustering seperti yang disajikan pada Tabel 2.

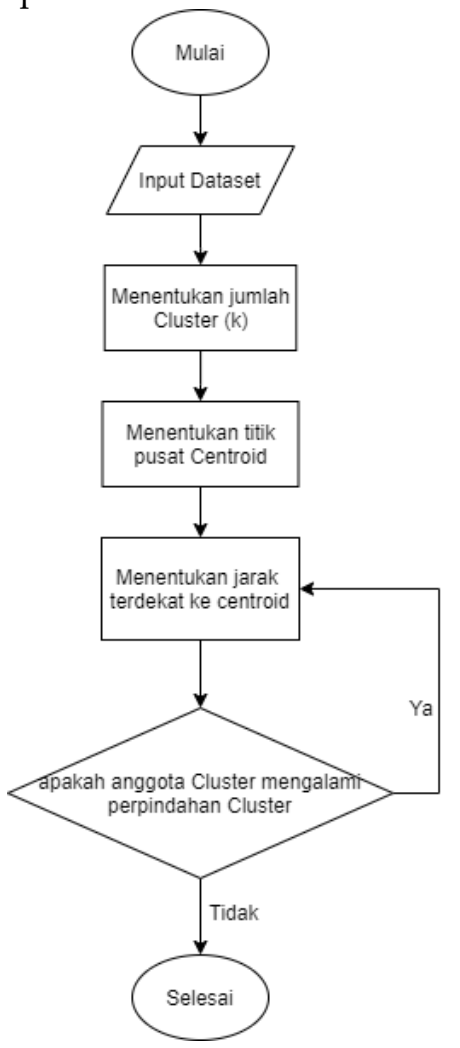

Gambar 1. Proses clustering dengan $k$-means

Tabel 2. Kriteria penilaian clustering berdasarkan Sillhouette Coefficient

\begin{tabular}{ll}
\hline Nilai Sillhouette Coefficient & \multicolumn{1}{c}{ Penilaian } \\
\hline $0,71-1,00$ & Struktur kuat \\
$0,51-0,70$ & Struktur baik \\
$0,26-0,50$ & Struktur lemah \\
$\leq 0,25$ & Struktur buruk \\
\hline
\end{tabular}

\section{Hasil dan Pembahasan}

Dalam melakukan penelitian ini penulis menggunakan bahasa pemrograman Python, Google Colab dan beberapa library untuk menjalankan algoritma k-means. Dataset yang digunakan adalah dataset jumlah penduduk Jakarta dan data persebaran COVID-19 di wilayah Jakarta. Proses yang pertama dilakukan yaitu melakukan proses merge pada dataset1 dan dataset2. Proses merge ini dilakukan dengan cara menggabungkan dataset1 dan dataset2 yang memiliki nama_kelurahan yang sama. Proses merge ini dapat dilihat pada Gambar 2.

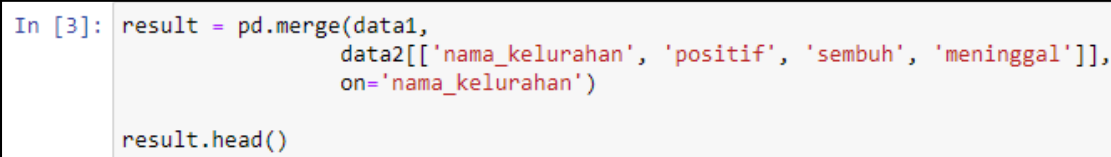

Gambar 1. Proses merge pada dataset1 dan dataset2

Selanjutnya akan dilakukan proses pembersihan data atau data cleaning. Proses cleaning akan dilakukan penghapusan subset data yang tidak menjadi perhatian pada penelitian atau menghapus data kosong yang berada di dalam dataset. Setelah proses cleaning, maka tersisa informasi kecamatan, nama_kelurahan, jumlah_penduduk, positif, sembuh, dan meninggal. Data yang dihasilkan disajikan pada Gambar 3.

Data yang akan diproses berjumlah 191 data seperti yang terlihat pada Gambar 3. Proses selanjutnya yaitu proses slicing pada dataset untuk membuat sebuah objek irisan. Kolom yang 
dibutuhkan yaitu kolom 3 (positif) dan kolom 4 (sembuh). Perintah dan hasil dari proses slicing ini dapat dilihat pada Gambar 4.

\begin{tabular}{|rrrrrrr|}
\hline & kecamatan & nama_kelurahan & jumlah-penduduk & positif & sembuh & meninggal \\
\hline 0 & PENJARINGAN & PENJARINGAN & 109567 & 156 & 77 & 5 \\
1 & PENJARINGAN & KAMAL MUARA & 15051 & 16 & 12 & 1 \\
2 & PENJARINGAN & KAPUK MUARA & 43025 & 18 & 14 & 2 \\
3 & PENJARINGAN & PEJAGALAN & 90327 & 31 & 23 & 3 \\
4 & PENJARINGAN & PLUIT & 55885 & 50 & 36 & 5 \\
$\ldots$ & $\ldots$ & $\ldots$ & $\ldots$ & $\ldots$ & $\ldots$ & $\ldots$ \\
186 & GROGOL PETAMBURAN & TANJUNG DUREN SELATAN & 2761 & 40 & 26 & 5 \\
187 & GROGOL PETAMBURAN & TANJUNG DUREN UTARA & 15047 & 18 & 9 & 1 \\
188 & KALIDERES & TEGAL ALUR & 74349 & 23 & 17 & 1 \\
189 & GROGOL PETAMBURAN & TOMANG & 8843 & 91 & 59 & 2 \\
190 & GROGOL PETAMBURAN & WIJAYA KUSUMA & 90130 & 21 & 15 & 2 \\
191 & rOWS $\times 6$ ColumnS & & & & & \\
\hline
\end{tabular}

Gambar 2. Dataset jumlah penduduk Jakarta dan data persebaran COVID-19 di Jakarta

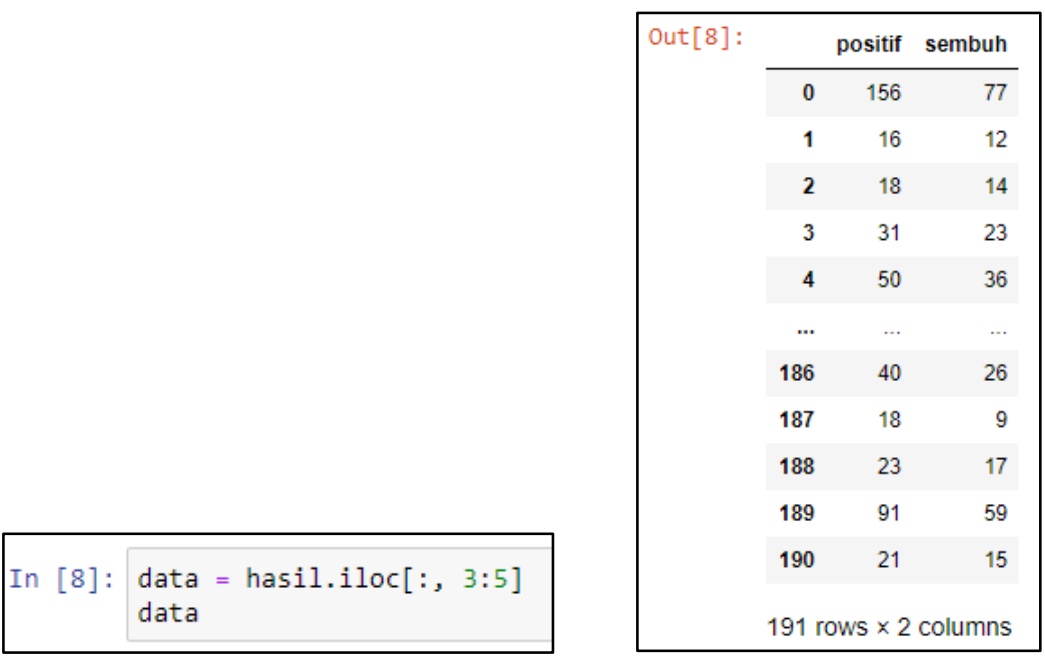

(a)

(b)

Gambar 3. Proses untuk slicing: (a) Perintah slicing; dan (b) Hasil slicing

Langkah selanjutnya adalah mengubah variabel data frame menjadi array dan menstandarkan kembali ukuran variable. Hal ini dilakukan supaya data yang telah dimodifikasi akan dapat kembali seperti jenis data awal sebelum data diubah menjadi array. Gambar 5 merupakan hasil dari menstandarkan ukuran variabel.

\begin{tabular}{|c|c|}
\hline In [11]: & $\begin{array}{l}\text { scaler = MinMaxScaler }(\text { ) } \\
\text { x_scaled = scaler.fit_transform(x_array) } \\
\text { x_scaled }\end{array}$ \\
\hline Out [11]: & 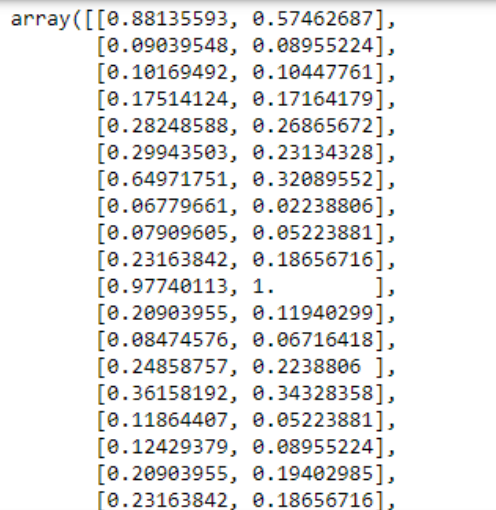 \\
\hline
\end{tabular}

Gambar 4. Hasil dari menstandarkan ukuran variabel

Penentuan nilai $k$ (n_clusters) atau nilai arbitrer dilakukan dengan menggunakan metode Elbow. Setelah nilai $k$ didapatkan, maka akan diukur kualitasnya menggunakan Sillhouette Coefficient. Sillhouette 
Coefficient akan mengukur sebarapa dekat setiap objek dalam satu cluster dekat dengan objek di cluster lain (Ogbuabor \& Ugwoke, 2018).

Dari Gambar 6 dapat dilihat bahwa nilai $k$ yang efektif adalah $k=2$, karena nilai $k$ yang efektif menurut Sillhouette Coeficient adalah saat skor Sillhouette mendekati 1. Sillhouette Coeficient dengan skor Sillhouette berada diantara -1 hingga +1 (Ogbuabor \& Ugwoke, 2018). Setelah itu, hal yang dilakukan adalah menentukan cluster dari hasil yang sudah didapatkan. Nilai cluster yang paling efektif yaitu $k=2$ (Gambar 7 (b)). Semua hasil cluster disajikan pada Gambar 7 dan Gambar 8. Adapun perintah dan hasil dari menentukan dan mengonfigurasi fungsi k-means dapat dilihat pada Gambar 9.

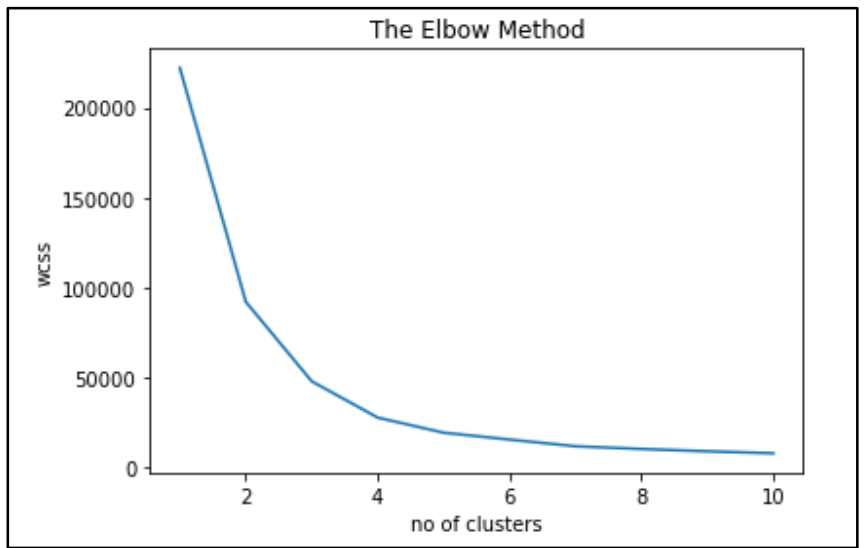

Gambar 5 Penentuan nilai $k$ dengan metode Elbow

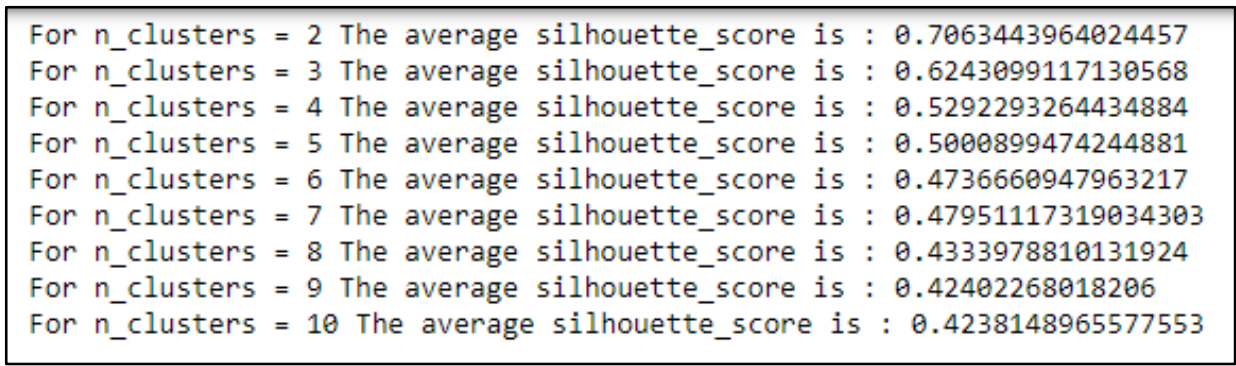

(a)
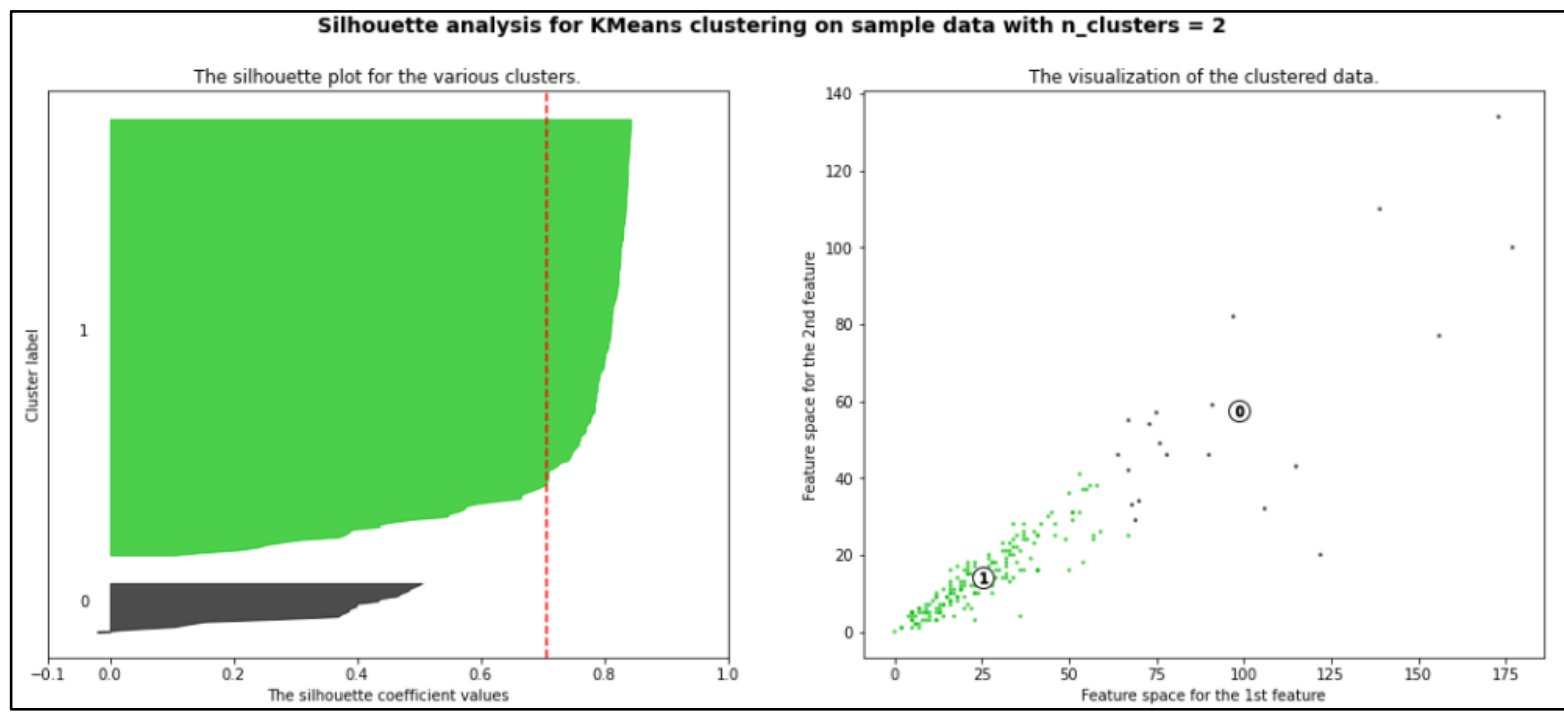

(b)

Gambar 6. Hasil Sillhouette Coeficient (a) nilai cluster dari 2 -10, (b) Jumlah cluster 2

Proses menampilkan pusat cluster dengan cara menampilkan centroid terlebih dahulu. Adapun cara untuk menampilkannya dapat dilihat pada Gambar 10. Dalam proses menampilkan data hasil cluster menambahkan kolom "klaster" ke dalam data frame pada Frame Driver dapat dilihat pada Gambar 11. Apabila sudah diklasterisasi, maka langkah selanjutnya yaitu menampilkan hasil cluster yang sudah didapatkan dari data hasil proses sebelumnya. Hasil cluster ini akan ditampilkan dalam 
bentuk visualisasi yang dapat dilihat pada Gambar 12. Keseluruhan data divisualisasikan berdasarkan tiap cluster dapat dilihat pada Gambar 13.

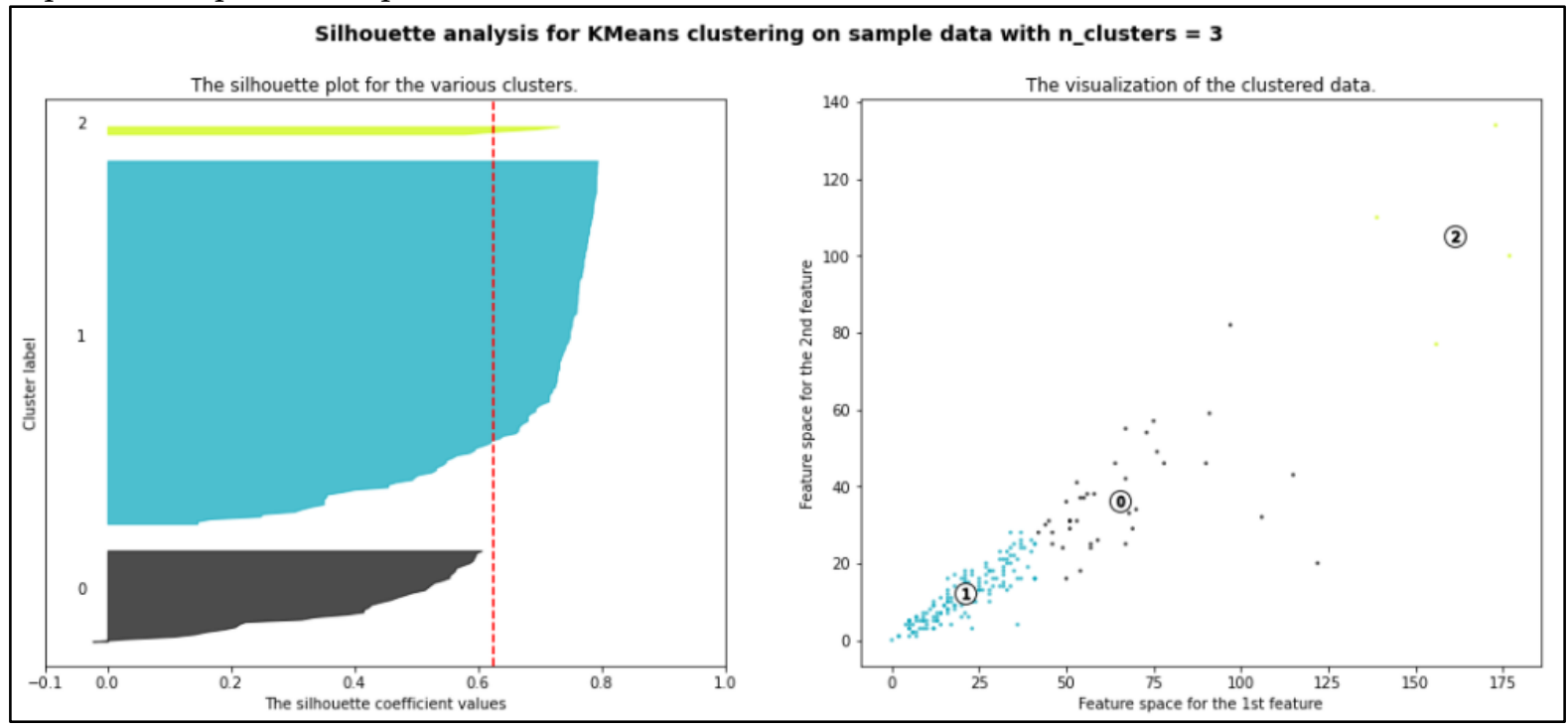

(a)

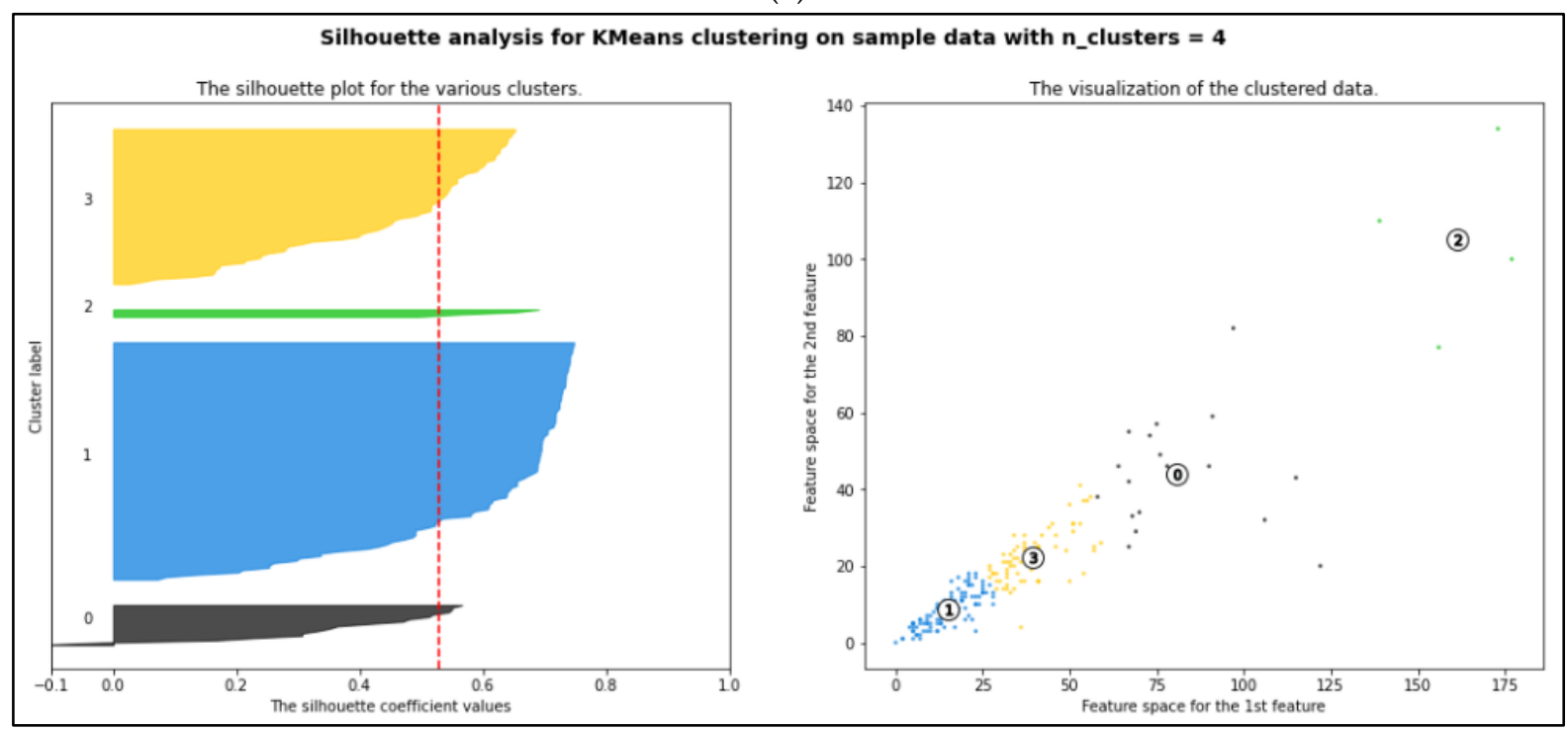

(b)

Gambar 8. Hasil Sillhouette Coeficient (a) Jumlah cluster 3, (b) Jumlah cluster 4.

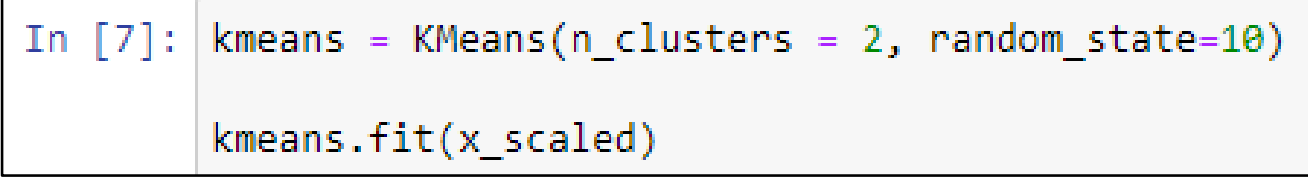

(a)

\section{Out [7]: KMeans(n_clusters=2, random_state=10)}

(b)

Gambar 9. Penentuan dan pengonfigurasi fungsi $k$-means: (a) Perintah; dan (b) Hasil (c) $k=2$ (d) $k=3$ (e) $k=4$

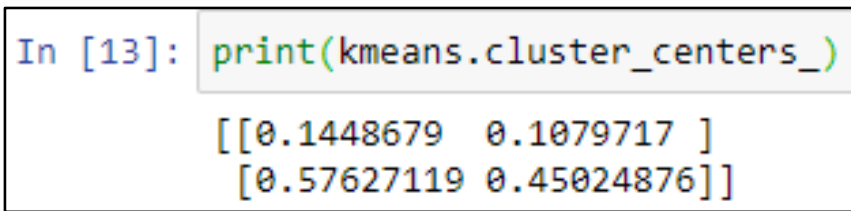

Gambar 10. Proses menampilkan pusat cluster 


\begin{tabular}{cc}
\multicolumn{2}{c}{ Tabel 1. Jumlah data pada setiap cluster } \\
\hline Cluster & Jumlah Data \\
\hline 0 & 173 \\
1 & 18 \\
\hline
\end{tabular}

Tabel 4. Data kelurahan yang memerlukan penanganan dan tidak

\begin{tabular}{clccc}
\hline No & NAMA KELURAHAN & POSITIF & SEMBUH & CLUSTER \\
\hline 1 & Kenari & 122 & 20 & 1 \\
2 & Kwitang & 23 & 3 & 0 \\
3 & Kramat & 67 & 42 & 1 \\
4 & Paseban & 70 & 34 & 1 \\
5 & Bungur & 16 & 7 & 0 \\
6 & Cempaka Putih Barat & 56 & 38 & 0 \\
7 & Rawasari & 17 & 11 & 0 \\
8 & Cempaka Putih Timur & 73 & 54 & 1 \\
9 & Kebon Sirih & 32 & 21 & 0 \\
10 & Gondangdia & 14 & 11 & 0 \\
11 & Cikini & 9 & 5 & 0 \\
12 & Menteng & 37 & 24 & 0 \\
13 & Pegangsaan & 106 & 32 & 1 \\
\hline
\end{tabular}

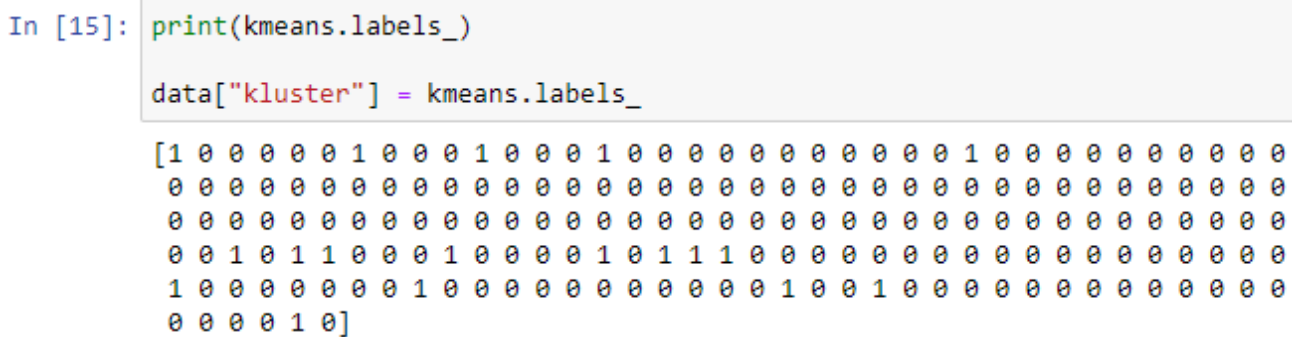

Gambar 117. Tampilan data hasil cluster dan penambahan kolom

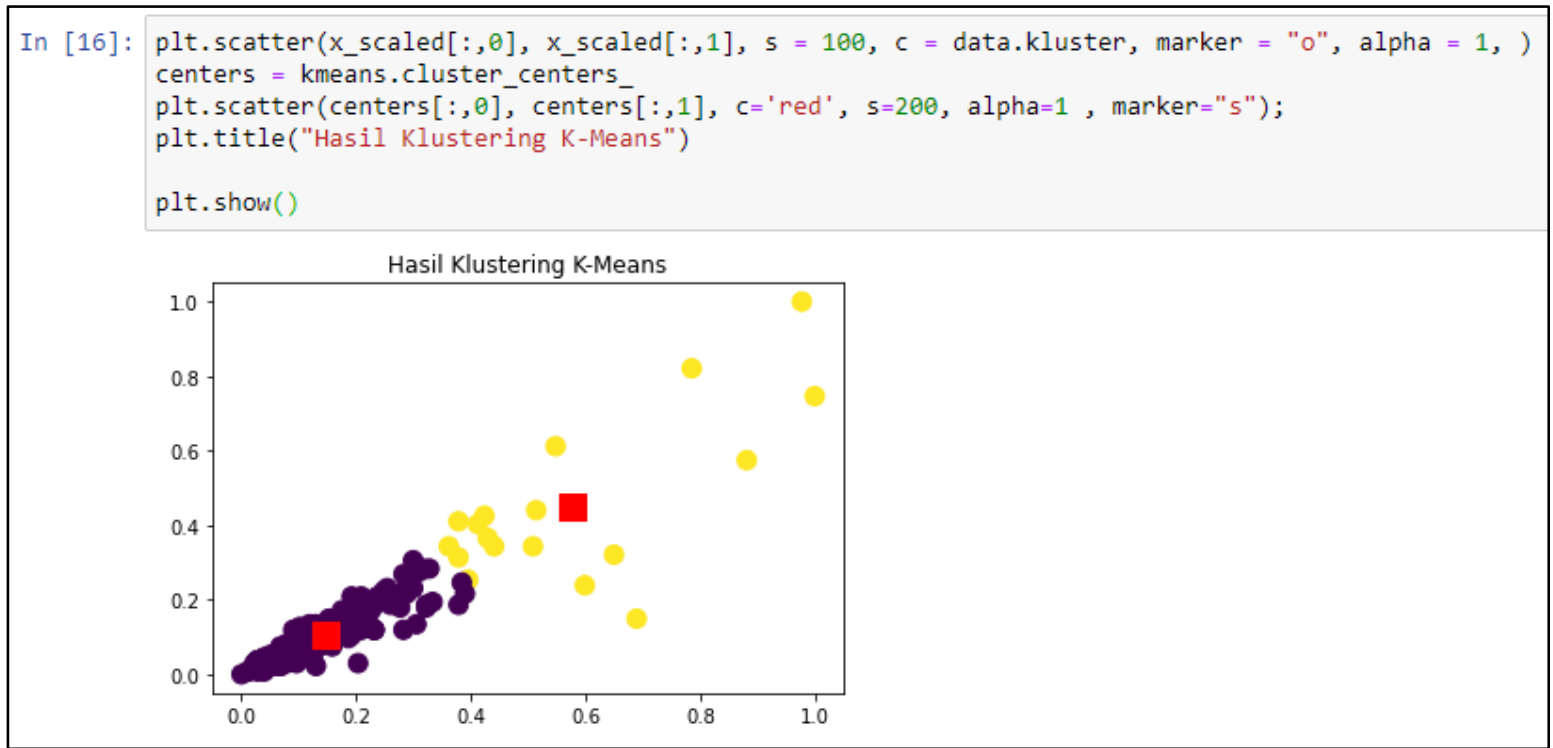

Gambar 128. Visualisasi dari hasil cluster

Jumlah data untuk setiap cluster yaitu untuk cluster 0 berjumlah 173, sedangkan untuk cluster 1 berjumlah 18 data. Jumlah data pada setiap cluster dapat dilihat pada Tabel 3. Tabel 4 ada 5 data yang masuk kedalam cluster 1 yang merupakan daerah yang memerlukan penanganaan COVID-19. Cluster 0 tidak diperlukan penanaganaan khusus untuk mengetahui bagaimana persebaran wabah COVID-19. 


\section{Kesimpulan}

Kesimpulan yang berhasil didapatkan dari penelitian ini menggunakan data COVID-19 didapat 2 cluster. Pada cluster 0 terdapat 173 data, sedangkan pada cluster 1 terdapat 18 data. Hasil yang sudah didapatkan, dapat diketahui bahwa metode $k$-means dapat memberikan informasi persebaran daerahdaerah mana yang perlu diberikan penangan COVID-19. Cempaka Putih Timur, Pegangsaan, Petamburan, Jembatan besi merupakan kelurahan yang perlu ditindaklanjuti dalam penanganan COVID-19. Persebaran data dapat digunakan sebagai informasi daerah-daerah yang memiliki jumlah kesembuhan tertinggi dan terendah untuk memberikan keputusan kepada pemerintah.

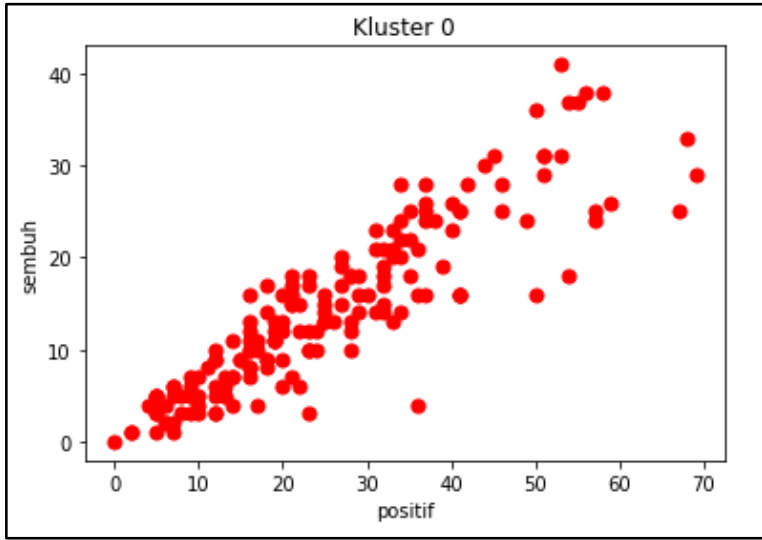

(a)

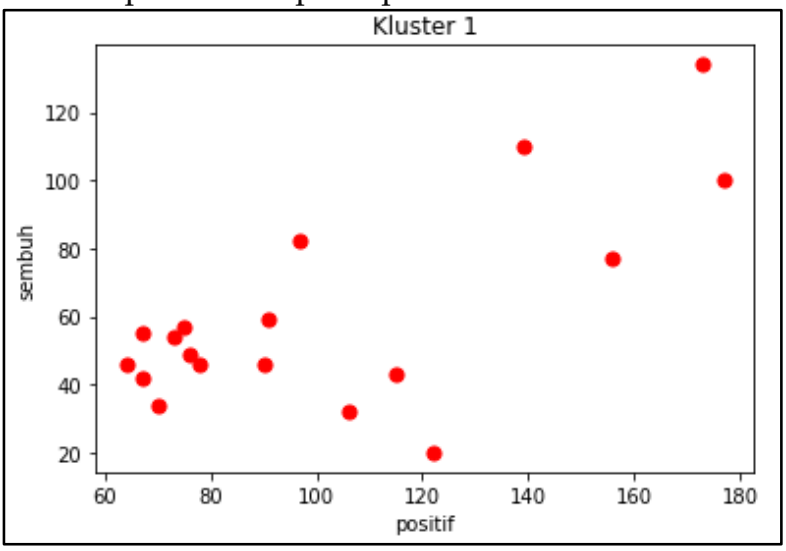

(b)

\section{Referensi}

Gambar 13. Visualisasi data: (a) cluster 0; (b) cluster 1

Bastian, A., Sujadi, H., \& Febrianto, G. (2018). Penerapan Algoritma k-Means Clustering Analysis Pada Penyakit Menular Manusia (Studi Kasus Kabupaten Majalengka). Jurnal Sistem Informasi (Journal of Information System), 14(1), 26-32.

Budiman, R., \& Rudianto, R. (2019). Penerapan Data Mining Untuk Menentukan Lokasi Promosi Penerimaan Mahasiswa Baru Pada Universitas Banten Jaya (Metode K-Means Clustering). Protekinfo: Jurnal Pengembangan Riset dan Observasi Teknik Informatika, 6(1), 6-14.

Dwitri, N., Tampubolon, J. A., Prayoga, S., Zer, F. I., \& Hartama, D. (2020). Penerapan Algoritma kMeans dalam Menentukan Tingkat Penyebaran Pandemi COVID-19 di Indonesia. JurTI (Jurnal Teknologi Informasi), 4(1), 128-132.

Fitriana, R., Saragih, J., \& Hasyati, B. A. (2018). Perancangan Model Sistem Intelijensia Bisnis untuk Menganalisis Pemasaran Produk Roti di Pabrik Roti Menggunakan Metode Data Mining dan Cube. Jurnal Teknologi Industri Pertanian, 28(1), 113-126.

Gustientiedina, G., Adiya, M., \& Desnelita, Y. (2019). Penerapan Algoritma K-Means Untuk Clustering Data Obat-Obatan Pada RSUD Pekanbaru. Jurnal Nasional Teknologi dan Sistem Informasi (TEKNOSI), 5(1), 17-24.

Indraputra, R. A., \& Fitriana, R. (2020). K-Means Clustering Data COVID-19. Jurnal Teknik Industri, 10(3), 275-282.

Jakarta, P. (2021). Data Pemantauan COVID-19. Jakarta: Pemprov Jakarta. Retrieved April 4, 2021, from https://corona.jakarta.go.id/id/data-pemantauan

Kaufman, L., \& Rousseeuw, P. J. (2005). Finding Groups in Data: An Introduction to Cluster Analysis. Wiley.

Lesmana, S., Akbari, A. F., Rahman, E. Y., \& Gustian, D. (2020). Penerapan K-Means dalam Efektivitas Pembelajaran ELearning pada Masa Pandemi Covid-19. Seminar Nasional Informatika 2020 (SEMNASIF 2020), (pp. 100-110).

Madhulatha, T. S. (2012). An Overview on Clustering Methods. IOSR Journal of Engineering, 2(4), 719 725.

Maulida, L. (2018). Penerapan Datamining dalam Mengelompokkan Kunjungan Wisatawan ke Objek Wisata Unggulan di Prov. DKI Jakarta dengan k-Means. JISKA (Jurnal Informatika Sunan Kalijaga), 2(3), 167-174.

Noviyanto, N. (2020). Penerapan Data Mining dalam Mengelompokkan Jumlah Kematian Penderita COVID-19 Berdasarkan Negara di Benua Asia. Paradigma, 22(2), 183-188. 
Ogbuabor, G., \& Ugwoke, F. N. (2018). Clustering Algorithm for a Healthcare Dataset Using Silhouette Score Value. International Journal of Computer Science \& Information Technology (IJCSIT), 10(2), 27-37.

Rembulan, G. D., Wijaya, T., Palullungan, D., Alfina, K. N., \& Qurthuby, M. (2020). Kebijakan Pemerintah Mengenai Coronavirus Disease (COVID-19) di Setiap Provinsi di Indonesia Berdasarkan Analisis Klaster. JIEMS (Journal of Industrial Engineering and Management Systems), 13(2), 74-86.

Sindi, S., Ningse, W. R., Sihombing, I. A., Zer, F. I., \& Hartama, D. (2020). Analisis Algoritma k-Medoids Clustering dalam Pengelompokan Penyebaran COVID-19 di Indonesia. JurTI (Jurnal Teknologi Informasi), 4(1), 166-173.

Solichin, A., \& Khairunnisa, K. (2020). Klasterisasi Persebaran Virus Corona (Covid-19) Di DKI Jakarta Menggunakan Metode K-Means. Fountain of Informatics Journal, 5(2), 52-59.

Suwandi, S. I., Situmorang, A., \& Rakhmawati, N. A. (2021). Analisis privasi data pengguna contact tracing application pengendalian COVID-19 di Indonesia berdasarkan PERPRES RI No. 95 tahun 2018 tentang sistem pemerintahan berbasis elektronik. Teknologi: Jurnal Ilmiah Sistem Informasi, $1(11), 46-58$.

Taslim, T., \& Fajrizal, F. (2016). Penerapan algorithma k-mean untuk clustering data obat pada puskesmas rumbai. Jurnal Teknologi Informasi \& Komunikasi Digital Zone, 7(2), 108-114.

Untoro, M. C., \& Buliali, J. L. (2018). Penanganan imbalance class data laboratorium kesehatan dengan Majority Weighted Minority Oversampling Technique. Register: Jurnal Ilmiah Teknologi Sistem Informasi, 4(1), 23-29.

Untoro, M. C., Praseptiawan, M., Widianingsih, M., Ashari, I. F., Afriansyah, A., \& Oktafianto, O. (2020). Evaluation of Decision Tree, k-NN, Naive Bayes and SVM with MWMOTE on UCI Dataset. Journal of Physics: Conference Series, 1477.

Zubair, M., Iqbal, M. A., Shil, A., Haque, E., Hoque, M. M., \& Sarker, I. H. (2020). An Efficient K-means Clustering Algorithm for Analysing COVID-19. 